\section{Erythrocyte parameters and condition factor of Gymnotus spp. (Gymnotiformes: Gymnotidae) under culture conditions}

\author{
Parâmetros eritrocitários e fator de condição de Gymnotus spp. \\ (Gymnotiformes: Gymnotidae) em condições de cultivo
}

\begin{abstract}
Arlene Sobrinho Ventura', Gabriela Tomas Jerônimo² , Giovanni Henrique Ferri³ , Santiago Benites de Pádua4, Maurício Laterça Martins ${ }^{5}$ \& Márcia Mayumi Ishikawa ${ }^{6 *}$

'Veterinary, MSc., Dr. student in Animal Sciency. Universidade Federal de Mato Grosso do Sul - UFMS, Campo Grande, MS, Brasil ${ }^{2}$ Aquaculture Engineer, Dr., Post doctorate. Universidade Nilton Lins, Manaus, AM, Brasil

${ }^{3}$ Biologist, MSc., Student in Animal Biology. Universidade Estadual de Campinas - UNICAMP, Campinas, SP, Brasil

${ }^{4}$ Veterinary, MSc., Aquaculture Product Manager. AQUA - Laboratório Biovet, Vargem Grande Paulista, SP, Brasil

${ }^{5}$ Biologist, Dr., Post doctorate. Laboratório AQUOS - Sanidade de Organismos Aquáticos, Departamento de Aquicultura, Universidade Federal de Santa Catarina - UFSC, Florianópolis, SC, Brasil

${ }^{6}$ Veterinary, Dr. Embrapa Meio Ambiente - EMBRAPA, CNPMA - Centro Nacional de Pesquisa de Monitoramento e Avaliação de Impacto Ambiental, Jaguariúna, SP, Brasil
\end{abstract}

\begin{abstract}
The aim of this study was to evaluate the erythrocyte variables and body conditions of tuvira, Gymnotus spp., under culture conditions. A total of 42 fish with an average weight of $42.9 \pm 31.8 \mathrm{~g}$ and average length of $23.7 \pm 3.3 \mathrm{~cm}$ from a commercial "bait house" were used. After fish anesthesia with clove oil, $1.5 \mathrm{~mL}$ of blood was withdrawn by caudal vein puncture for the determination of red blood cell count, hematocrit, hemoglobin, mean corpuscular volume (MCV), mean corpuscular hemoglobin concentration (MCHC), and body condition (Kn). The number of erythrocytes varied from 0.880 to $3.940 \times 10^{6} \mu \mathrm{l}^{-1}$, hematocrit varied from 20.0 to $51.5 \%$, hemoglobin concentration varied from 4.4 to $14.9 \mathrm{~g} \mathrm{dl}^{-1}, \mathrm{MCV}$ varied from 121.8 to $250.0 \mathrm{fL}^{-1}$, MCHC varied from 15.0 to $35.6 \mathrm{dl} \mathrm{g}^{-1}$, and Kn was $1.00 \pm 0.041$. Erythrocyte values of Gymnotus spp. herein obtained were within the characteristics presented by other cultured fish species. The data evaluated in this work demonstrated that the tuvira kept in the "bait house" presented good body conditions and healthiness.
\end{abstract}

Keywords: hematology, health, bait house, marketing.

\section{Resumo}

O objetivo deste trabalho foi avaliar as variáveis eritrocitárias e a condição corporal e higidez de tuvira, Gymnotus spp. sob condições de cultivo. Um total de 42 peixes com peso médio de 42,9 431,8 g e comprimento médio de 23,7 $\pm 3,3 \mathrm{~cm}$ oriundos de casa de iscas comercial foram utilizados. Após anestesia dos peixes com óleo de cravo, 1,5 mL de sangue foi retirado por punção do vaso caudal para determinação da contagem total de eritrócitos, percentual de hematócrito, taxa de hemoglobina, volume corpuscular médio (VCM), concentração de hemoglobina corpuscular média (CHCM) e fator de condição (Kn). O número de eritrócitos variou de 0,880 a 3,940 × $10^{6} \mu^{-1}{ }^{-1}$, hematócrito variou de 20,0 a 51,5\%, taxa de hemoglobina de

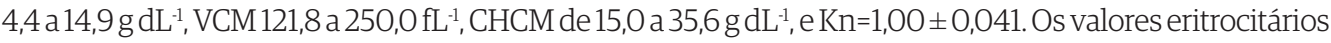
de Gymnotus spp., aqui obtidos encontraram-se dentro das características apresentadas por outras espécies de peixes cultivadas. Os dados avaliados neste trabalho demonstraram que as tuviras mantidas nos isqueiros apresentaram boas condições corporais e higidez.

Palavras-chave: hematologia, saúde, casa de iscas, comercialização.

\section{Introduction}

The gymnotid fish tuvira, Gymnotus spp., is currently one of the live bait species of major commercial importance in Mato Grosso do Sul, Brazil, being a source of income for many populations living close to rivers (Pádua et al., 2012). It is estimated that the catch of this fish reaches the mark of approximately 15 million baits a year, and losses during the period of storage in commercial bait houses are approximately 14\% (Moraes \& Espinoza, 2001).
How to cite: Ventura, A. S., Jerônimo, G. T., Ferri, G. H., Pádua, S. B., Martins, M. L., \& Ishikawa, M. M. (2018). Erythrocyteparameters and conditionfactor of Gymnotus spp. (Gymnotiformes: Gymnotidae) under culture conditions. Brazilian Journal of Veterinary Medicine, 40, e20318. doi: 10.29374/2527-2179.bjvm020318

Financial support: Fundect and project BRSAqua (EMBRAPA/BNDES).

Conflict of interests: No conflict of interests declared concerning the publication of this article.

Received: September 19, 2017.

Accepted: June 04, 2018

The study was carried out at Embrapa Agropecuária Oeste, Dourados, MS, Brazil.

\section{*Correspondence}

Márcia Mayumi Ishikawa

Embrapa Meio Ambiente - EMBRAPA, CNPMA - Centro Nacional de Pesquisa de Monitoramento e Avaliação de Impacto Ambiental

Rod. SP 340, km 127,5, CP 69, Tanquinho Velho

CEP 13918-110 - Jaguariúna (SP), Brasil E-mail:marcia.ishikawa@embrapa.br 
This genus stands out because it belongs to the food habit of important species used in sport fishing, such as Salminus brasilienses and Pseudoplatystoma sp. (Pádua et al., 2012; Ishikawa et al., 2014). Because of the peculiar characteristics of this species, they live in environments that favor disease development, such as lentic habitats and places with high organic matter content, where they take shelter and search for food, such as fish, vegetables, sediment, protozoans, mollusks, and crustaceans (Resende et al., 2006).

Hematological studies are necessary to characterize physiologically a fish species, both in its natural environment and in captivity. They can indicate stressful conditions and anemic processes, as well as provide information on the respiratory capacity of fish species (Tavares-Dias \& Moraes, 2004). They are important for the knowledge on equilibrium and pathological conditions, in determining the influence of pathophysiological conditions that can affect homeostasis, and in contributing to the diagnosis of adverse conditions, in addition to the understanding of the health status of fish (Ranzani-Paiva et al., 2013).

Sanitary studies on this fish genus are scarce, especially in the environment of storage and commercialization in the so-called "bait houses". In these places, the animals are kept after being caught in a natural environment in which sanitary conditions are not adequate to maintain the fish health (Ishikawa et al., 2014; Ventura et al., 2016), making them suitable for the development of pathogens, which can affect their health and survival.

In view of the need for information on the identification and control of stressful situations and diseases, hematological analyzes and evaluations of the condition factor assume importance as an auxiliary tool in the diagnosis, in order to ensure the health of fish. The aim of this study was to evaluate the hematological characteristics and the condition factor of tuvira, Gymnotus spp., from a "bait house" located in the Midwestern Brazil.

\section{Material and methods}

A total of 42 tuvira specimens from a commercial "bait house", located in Dourados in the state of Mato Grosso do Sul, Brazil, were evaluated. The animals were kept in masonry tanks, with high storage density and little water renewal. During the period the fish were kept in the "bait house", their feeding was based on termites, sardines, and even other crushed tuvira.

The fish were anesthetized in clove oil solution $\left(150 \mathrm{mg} / \mathrm{L}^{-1}\right)$ for biometry and blood collection. The 42 individuals were weighed in a semi-analytical scale and their size was measured with the aid of a ruler (Ethics Committee No. 005/2011-CEUA / UFGD).

After anesthesia, blood samples were collected by caudal venipuncture using syringes containing 10\% EDTA. They were measured as hemoglobin ( $\mathrm{Hb}$ ) by the cyanmethemoglobin method (Ranzani-Paiva et al., 2013), hematocrit (Hct), using the microhematocrit method according to Goldenfarb et al.(1971), total number of erythrocytes (RBC) after dilution at 1:200 in formaldehyde-citrate solution and counted in a Neubauer chamber, according to Ranzani-Paiva et al. (2013). From these data, mean corpuscular volume (MCV) and mean corpuscular hemoglobin concentration (MCHC) were calculated according to Ranzani-Paiva et al. (2013).

The determination of blood glucose was performed by strips using a portable device (Accu-chek ${ }^{\circledR}$. Total plasmatic protein concentration was determined with a portable refractometer. Length-weight relationship and condition factor were determined from the biometric data. Length-weight data were analyzed following the equation $\mathrm{Wt}=a \mathrm{~L} . \mathrm{b}$, where $\mathrm{Wt}$ is the total weight in grams, $\mathrm{L}$ is the total length in $\mathrm{cm}$, and $a$ and $b$ are constants. The condition factor (Kn) was calculated by equation $\mathrm{Kn}=P$ observed $/ P$ expected, where ' $P$ observed' is the weight obtained from weighing each individual and ' $P$ expected' is the weight determined by the length-weight ratio curve (Le Cren, 1951).

\section{Results and discussion}

The fish evaluated presented an average weight of $42.9 \pm 31.8 \mathrm{~g}$ and a mean length of $23.7 \pm 3.3 \mathrm{~cm}$. Regarding water quality parameters, dissolved oxygen in the water was $1.05 \pm 0.71 \mathrm{mg} \mathrm{L}^{-1}$ and temperature was $21.87 \pm 1.33^{\circ} \mathrm{C}$. The temperature and oxygen observed can be considered ideal for the species, since the tuvira present bimodal breathing and highly vascularized swimming 
bladder (Moraes et al., 2002), which allows them to face low levels of oxygen and survive in hypoxic environments.

The length-weight relationship of the animals (Figure 1) may be influenced by numerous factors, such as food availability, reproductive period, as well as abiotic factors characteristic of the environment in which the animals are kept. All of these can affect the estimation of the length-weight relationship, which can result in variation in the regression coefficient.

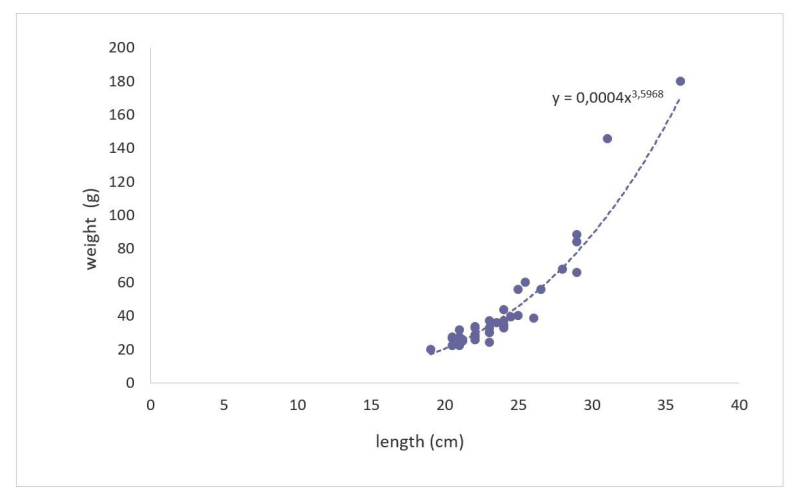

Figure 1. Length-weight relationship of tuvira, Gymnotus spp., from a commercial "bait house" of Mato Grosso do Sul, Brazil.

The condition factor is a quantitative measure of fish welfare, which can provide a physical and physiological relation of the environment in which it lives, so it must remain constant regardless of the size the fish may have in a certain period of life (Gomiero \& Braga, 2003). The factor $\mathrm{Kn}=1.00$ for fish kept in the "bait house" can indicate that the fish were in good health (Table 1).

Table 1. Mean values \pm standard deviation (SD), variation, and coefficient of variation (CV) of the erythrocyte parameters of tuvira, Gymnotus spp., (n= 42) from a commercial "bait house" of Mato Grosso do Sul, Brazil.

\begin{tabular}{cccc}
\hline Parameters & Mean \pm SD & Minimum-Maximum & CV (\%) \\
\hline weight $(\mathrm{g})$ & $42.9 \pm 31.8$ & $20.2-180.0$ & 74.1 \\
length (cm) & $23.7 \pm 3.3$ & $19.0-36.0$ & 13.9 \\
Kn & $1.00 \pm 0.041$ & $0.899-1.083$ & 4.1 \\
Glucose (mg/dL) & $69.6 \pm 28.6$ & $11.0-158.0$ & 41.1 \\
Total protein (mg/dL) & $4.2 \pm 1.0$ & $2.8-7.8$ & 23.8 \\
Erythrocytes (x10 /L) & $2.104 \pm 0.673$ & $0.880-3.940$ & 31.9 \\
Hemoglobin (g/dL) & $8.2 \pm 2.7$ & $4.4-14.9$ & 32.9 \\
Hematocrit (\%) & $35.0 \pm 8.9$ & $20.0-51.5$ & 25.4 \\
MCV (fL) & $172.0 \pm 29.7$ & $121.8-250.0$ & 17.3 \\
MCHC (g/dL) & $23.5 \pm 4.7$ & $15.0-35.6$ & 20 \\
\hline
\end{tabular}

MCV = Mean corpuscular volume; $\mathrm{MCHC}=$ Mean corpuscular hemoglobin concentration; $\mathrm{Kn}$ = Relative condition factor.

Hematological variables allow us to evaluate the health status of animals (Lopes et al., 2007). The results of this study demonstrated the erythrocyte variables of Gymnotus spp. in a commercial "bait house", which were oval with a central nucleus accompanying the cell shape, with compact chromatin and without nucleoli (Figure 2); the morphology of the erythrocytes correspond to that observed in other cultured fish species. Erythrocytes contain the respiratory pigment, which is responsible for $\mathrm{O}_{2}$ transport and part of $\mathrm{CO}_{2}$ transport in the blood. Any deficiency in the erythrocyte will be translated into a lack of $\mathrm{O}_{2}$ in the tissues (Ranzani-Paiva et al., 2004). 


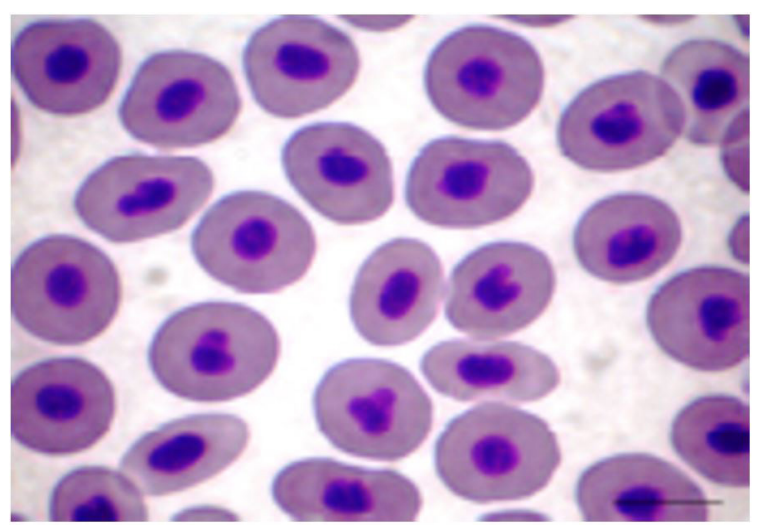

Figure 2. Blood cells of tuvira, Gymnotus spp., and erythrocyte staining with May-Grünwald-Giemsa-Wright. Bar $=10 \mu \mathrm{m}$.

The hematological profile of fish is directly related to the genus and gonadal development, nutritional state, seasonality, and environment (Tavares-Dias \& Moraes, 2004; Babalola et al., 2009). Total plasma protein values of Gymnotus spp. were lower than those observed in tuvira after anesthesia with different concentrations of clove oil (Pádua et al., 2012). In contrast, they were similar to those found in catfish Ictalurus punctatus (Tavares-Dias \& Moraes, 2007) and Sorubim lima (Bianchi et al., 2014) and they were lower than those observed in the hybrid Pseudoplatyatoma coruscans (Jerônimo et al., 2015). The total plasma protein concentration may vary according to the immune status and should be considered an interspecific difference (Tavares-Dias \& Moraes, 2004).

Changes in the number of fish erythrocytes indicate responses to the oxygen levels to which the animals are exposed, so hemoglobin, MCV, and MCHC are important to identify and classify the type of anemia that can occur in fish (Labarrère et al., 2012).

Hematocrit corresponds to the volume occupied by erythrocytes contained in a certain amount of whole blood. The values of the erythrogram of Gymnotus spp. were similar to the values found for the species (Pádua et al., 2012). Because of the low concentrations of dissolved oxygen in the water, it can be stated that the fish increased the production of red blood cells to improve oxygen transport capacity, thus compensating for reduced availability in the medium (Jerônimo et al., 2011).

Glucose concentration is related to many stressors, such as temperature variation, handling, and transportation (Urbinati et al., 2004). It is an indicator of physiological disturbance as it is the main source of energy used by fish to withstand adverse situations (Morgan \& Iwama, 1997). The glucose values obtained in this work were higher than those found for catfish I. punctatus (Tavares-Dias \& Moraes, 2007) and smaller than those observed in silver catfish Rhamdia quelen (Higuchi et al., 2011), indicating that these differences may be species specific.

The values of red blood cells for Gymnotus sp varied, which may be due to nutritional factors and age, since the animals sampled were of different ages. However, they remained within the reference standards for the species (Rodrigues et al., 2018). However, nutritional status, age, and environmental conditions are the main factors responsible for the changes in the erythrocyte count of fish (Tavares-Dias \& Moraes, 2004; Ranzani-Paiva et al., 2013). The length-weight relationship, as well as the condition factor obtained in this study demonstrated that the tuvira presented good body condition related to environmental conditions, food, and welfare.

\section{Conclusion}

The erythrocyte characteristics of tuvira, Gymnotus spp., under culture conditions in the "bait house" were similar to other cultured fish species, and they can be used to evaluate the fish health status. The fish kept in the "bait house" presented good body conditions and the total count of erythrocyte remained within the reference values for the species. 


\section{Acknowledgements}

The authors thank Fundect (23/200.202/2010) and project BRSAqua (Embrapa/BNDES) for financial support, and National Council for Scientific and Technological Development (CNPq 305869/2014-0) for research grant to M.L. Martins and Post-Doctoral scholarship (CNPq 168148/2017-0) to G.T. Jerônimo.

\section{References}

Babalola, T. O. O., Adebayo, M. A., Apata, D. F., \& Omotosho, J. S. (2009). J.S. Effect of dietary alternative lipid sources on haematological parameters and serum constituents of Heterobranchus longifi lis fi ngerlings. Tropical Animal Health and Production, 41(3), 371-377. http://dx.doi.org/10.1007/s11250-008-9199-1. PMid:18607765.

Bianchi, M. B., Jerônimo, G. T., Pádua, S. B., Satake, F., Ishikawa, M. M., Tavares-Dias, M., \& Martins, M. L. (2014). The hematological profile of farmed Sorubim lima. Veterinarski Arhiv, 84(6), 677-690.

Goldenfarb, P. B., Bowyer, F. P., Hall, E., \& Brosious, E. (1971). Reproductibility in the hematology laboratory: the microhematocrit determinations. American Journal of Clinical Pathology, 56(1), 35-39. http://dx.doi.org/10.1093/ ajcp/56.1.35. PMid:5556212.

Gomiero, L. M., \& Braga, F. M. S. (2003). Relação peso-comprimento e fator de condição para Cichla cf. ocellaris e Cichla monoculus (Perciformes, Cichlidae) no reservatório de Volta Grande, Rio Grande-MG/SP. Acta Scientiarum. Biological Sciences, 25(1), 79-86. http://dx.doi.org/10.4025/actascibiolsci.v25i1.2119.

Higuchi, L. H., Feiden, A., Maluf, M. L. F., Dallagnol, J. M., Zaminhan, M., \& Boscolo, W. R. (2011). Avaliação eritrocitária e bioquímica de jundiás (Rhamdia quelen) submetidos à dieta com diferentes níveis protéicos e energéticos. Ciência Animal Brasileira, 12(1), 70-75. http://dx.doi.org/10.5216/cab.v12i1.8986.

Ishikawa, M. M., Marques, D. K. S., Santos, J. S., Ventura, A. S., Pádua, S. B., Silva, T. S. C., \& Martins, L. M. (2014). Recomendações para redução da mortalidade na estocagem de tuviras em isqueiros (Circular Técnica, No. 25). Dourados: Embrapa Agropecuária Oeste.

Jerônimo, G. T., Brum, A., Pádua, S. B., Gonçalves, E. L. T., Capecci, R. S., Ishikawa, M. M., \& Martins, M. L. (2015). Haematological Parameters of the Hybrid Surubim (Pseudoplatystoma reticulatum $\times$ P. corruscans) farmed in Brazil. Brazilian Archives of Biology and Technology, 58(2), 254-261. http://dx.doi.org/10.1590/S1516-8913201400180.

Jerônimo, G. T., Lafitte, L. V., Speck, G. M., \& Martins, M. L. (2011). Influência sazonal sobre os parâmetros hematológicos em culta tilápia do Nilo do sul do Brasil. Brazilian Journal of Biology = Revista Brasileira de Biologia, 71, 719-725.

Labarrère, C. R., Faria, P. M. C., Teixeira, E. A., \& Melo, M. M. (2012). Erythrogram of hybrids surubins (Pseudoplatystoma corruscans X P. reticulatum) kept at different stocking densities. Arquivo Brasileiro de Medicina Veterinária e Zootecnia, 64(2), 510-514. http://dx.doi.org/10.1590/S0102-09352012000200037.

Le Cren, E. D. (1951). The length-weight relationship and seasonal cycle in gonadal weight and condition in the perch Perca fluviatilis. Journal of Animal Ecology, 20(2), 201-219. http://dx.doi.org/10.2307/1540.

Lopes, S. T. A., Biondo, A. W., \& Santos, A. P. (2007). Manual de patologia clínica veterinária (3. ed.). Santa Maria: UFSM.

Moraes, A. S., \& Espinoza, L. W. (2001). Captura e a comercialização de iscas vivas em Corumbá-MS (Boletim de Pesquisa, No. 21). Corumbá: Embrapa Pantanal.

Moraes, G., Avilez, I. M., Altran, A. E., \& Barbosa, C. C. (2002). Respostas bioquímicas e hematológicas de tuvira Gymnotus carapo (Linnaeus, 1758) exposta à hipóxia ambiental. Brazilian Journal of Biology= Revista Brasileira de Biologia, 62, 633-640. http://dx.doi.org/10.1590/S1519-69842002000400011.

Morgan, J. D., \& Iwama, G. K. (1997). Measurements of stressed states in the field. In G. K. Iwama, A. D. Pickering, J. P. Sumpter \& C. B. Schreck (Eds.), Fish stress and health in aquaculture. Cambridge: Cambridge University Press.

Pádua, S. B., Ventura, A. S., Satake, F., Ishikawa, M. M., Hisano, H., Rotta, M. A., \& Arantes, F. C. (2012). Respostas hematológicas em tuvira após anestesia com diferentes concentrações de óleo de cravo. Boletim do Instituto de Pesca, 38(3), 181-188.

Ranzani-Paiva, M. J. T., Pádua, S. B., Tavares-Dias, M., \& Egami, M. M. I. (2013). Métodos para análise hematológica em peixes. Maringá: EDUEM. http://dx.doi.org/10.7476/9788576286530.

Ranzani-Paiva, M. J. T., Takemoto, R. M., \& Lizama, M. A. P. (2004). Sanidade de organismos aquáticos. In M. J. T. Ranzani-Paiva \& A. T. Silva-Souza (Eds.), Hematologia de peixes brasileiros. São Paulo: Varela.

Resende, E. K., Pereira, R. A. C., Sório, V. F., \& Galvão, E. M. (2006). Biologia da tuvira, Gymnotus cf. Carapo (Pisces, Gymnotidae) no baixo Rio Negro, Pantanal, Mato Grosso do Sul, Brasil (Boletim de Pesquisa, No. 67). Corumbá: Embrapa Pantanal.

Rodrigues, R. A., Silva, E. S., Marcondes, S. F., Galindo, G. M., Oliveira, G. G. D., Souza, A. D., Ragusa-Netto, J., \& Fernandes, C. (2018). Características hematológicas e biométricas da tuvira Gymnotus inaequilabiatus (Valenciennes, 1839) (Gymnotiformes: Gymnotidae) do Pantanal brasileiro. Anais da Academia Brasileira de Ciências, 90(1), 49-57. http://dx.doi.org/10.1590/0001-3765201720150824. PMid:29424384.

Tavares-Dias, M., \& Moraes, F. R. (2007). Haematological and biochemical reference intervals for farmed channel catfish. Journal of Fish Biology, 71(2), 383-388. http://dx.doi.org/10.1111/j.1095-8649.2007.01494.x. 
Tavares-Dias, M., \& Moraes, F. R. (2004). Hematologia de peixes Teleósteos. Ribeirão Preto: Villimpress.

Urbinati, E. C., Abreu, J., Camargo, A., \& Parra, M. (2004). Loading and transport stress in juvenile matrinxã (Brycon cephalus) at various densities. Aquaculture, 229(1-4), 389-400. http://dx.doi.org/10.1016/50044-8486(03)00350-8.

Ventura, A. S., Ishikawa, M. M., Gabriel, A. M. D. A., Silbiger, H. L. N., Cavichiolo, F., \& Takemoto, R. M. (2016) Histopathology from liver of tuvira (Gymnotus spp.) parasitized by larvae of nematodes. Ciência Rural, 46(7), 1233-1239. http://dx.doi.org/10.1590/0103-8478cr20150881. 